Discussion Paper No. 09-038

Intergenerational Transmission of Human Capital in Early Childhood

Katja Coneus and Maresa Sprietsma

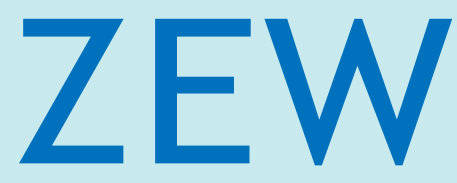

Zentrum für Europäische Wirtschaftsforschung $\mathrm{GmbH}$

Centre for European

Economic Research 
Discussion Paper No. 09-038

\title{
Intergenerational Transmission of Human Capital in Early Childhood
}

\author{
Katja Coneus and Maresa Sprietsma
}

Download this ZEW Discussion Paper from our ftp server:

ftp://ftp.zew.de/pub/zew-docs/dp/dp09038.pdf

Die Discussion Papers dienen einer möglichst schnellen Verbreitung von neueren Forschungsarbeiten des ZEW. Die Beiträge liegen in alleiniger Verantwortung der Autoren und stellen nicht notwendigerweise die Meinung des ZEW dar.

Discussion Papers are intended to make results of ZEW research promptly available to other economists in order to encourage discussion and suggestions for revisions. The authors are solely responsible for the contents which do not necessarily represent the opinion of the ZEW. 


\section{Non-technical summary}

It is a well-known fact that the level of parents' education is strongly correlated with the educational achievement of their children. This effect is more robust than that of any school or institutional factors. Moreover, differences in skills between children with less versus better educated parents are observed at an early age and have lasting effects on educational attainment.

Although the correlation between parents and children's educational attainment has been well documented, there is hardly any evidence as to what is behind the observed strong intergenerational transmission of human capital. Therefore the purpose of this paper is to shed some light inside the black box of transmission of human capital by disentangling the potential channels through which human capital is transmitted from mothers to their children. Using the German socio-economic panel (SOEP), we aim to identify what it is that more educated mothers do and that allows them to transmit human capital (i.e. skills) to their children at this early age. We proceed by successively including variables that are affected by maternal human capital and that may affect childrens' skills in a linear regression of maternal human capital on childrens' verbal, social and motor skills. These include birth weight, father support, institutional childcare attendance as well as the frequency of several activities with the child.

We focus on the skills of children at age 2-3 years. The psychological and pedagogical literature shows that at this age, considerable differences in skills already emerge between children with differently educated parents. Moreover, at this age, most German children have been exposed to (pre-)school and peer effects only in a limited way. We look at relatively large differences in maternal educational attainment. We distinguish between attaining an academic education, reaching a vocational degree versus not reaching either of these levels of education. These are used as proxies for human capital, including the human capital acquired in formal education but also human capital obtained through innate ability, educational values and other favorable environmental characteristics.

A first finding is that motor skills are not related to the level of maternal education. Secondly, according to our results, the included channels together account for the entire verbal and social skill gap between children from less versus better educated mothers at age three. Birth weight and the intensity of father's support are important channels of transmission of human capital for both verbal and social skills. Moreover, reading stories to the child is most relevant for the transmission of verbal skills whereas for social skills, a crucial channel for maternal human capital is the attendance of institutional childcare. This implies that there is important scope for reducing educational inequalities by encouraging attendance of institutional childcare before age three and by increasing parental awareness of the high relevance of early verbal stimulation such as through reading stories. 


\section{Zusammenfassung}

Es ist unumstritten, dass das Bildungsniveau der Eltern einen bedeutenden Einfluss auf die Bildung der Kinder hat. Dieser intergenerationale Effekt ist wichtiger als andere schulische oder institutionelle Faktoren. Unterschiede in den Fähigkeiten von Kindern zwischen Eltern mit geringerem Bildungsniveau und Eltern mit hohem Bildungsniveau offenbaren sich bereits in der Kindheit, noch bevor das Schulalter erreicht ist.

Obwohl dieser starke Zusammenhang in vielen Ländern mit unterschiedlichen Daten und für verschiedene Alterskohorten herausgestellt wurde, ist bis heute nicht klar, welche Faktoren hinter diesem Zusammenhang eigentlich stecken. Diese Arbeit hat es sich daher zum Ziel gesetzt, die „Black Box“ zu öffnen und potentielle Kanäle, die hinter der Weitergabe des Humankapitals stehen können, zu analysieren. Basierend auf den Daten des Sozio-oekonomischen Panels (SOEP) untersuchen wir, wie das Humankapital der Mutter, die verbalen, motorischen und sozialen Fähigkeiten der Kinder beeinflusst. In einem ersten Schritt wird der Gesamteffekt des Humankapitals der Mutter auf die Fähigkeiten des Kindes in einem linearen Modell ermittelt. Ausgehend von dieser Spezifikation werden nach und nach potentielle Kanäle eingefügt, von denen wir annehmen, dass sie vom Humankapital der Mutter abhängig sind und möglicherweise der Erwerb von Fähigkeiten fördern.

Betrachtet werden hier Kinder im Alter zwischen 2 und 3 Jahren, eine Gruppe, die in der ,klassischen“ Bildungsökonomie bisher wenig Beachtung gefunden hat. Diese Altersgruppe ist aber aus zwei Gründen besonders interessant: Einerseits zeigen Ergebnisse aus psychologischen und pädagogischen Studien, dass Unterschiede in der Entwicklung von Fähigkeiten schon zu Beginn des Lebens beobachtbar sind. Andererseits sind die meisten Kinder in diesem Alter im Wesentlichen durch die Einflüsse innerhalb der Familie geprägt, weniger durch Effekte der außerhäuslichen Betreuung oder durch Peereffekte.

Als erstes Ergebnis finden wir, dass die motorischen Fähigkeiten im Alter von 2-3 Jahren nicht vom Humankapital der Mutter abhängig sind. Zentrales Ergebnis dieser Studie ist, dass die hier untersuchten Kanäle den gesamten „Skill-Gap“ zwischen Müttern mit niedrigen und hohen Bildungsniveau erklären. Das Geburtsgewicht sowie die Unterstützung des Vaters bei der Betreuung der Kinder sind entscheidende Kanäle wie das Humankapital der Mutter Einfluss auf die Entwicklung der verbalen und der sozialen Fähigkeiten nehmen kann. Darüber hinaus spielt das Vorlesen von Geschichten für Kinder eine wesentliche Rolle für die Entwicklung verbaler Fähigkeiten, während die institutionelle Kinderbetreuung ein zentraler Faktor ist, der soziale Fähigkeiten beeinflussen kann. Bildungsungleichheiten könnten entsprechend dieser Ergebnisse durch die Förderung des Besuchs institutioneller Einrichtungen oder aber auch durch die Stimulation verbaler Kompetenzen, wie beispielsweise durch das Vorlesen von Geschichten, verringert werden. 


\title{
Intergenerational transmission of human capital in early childhood
}

\author{
Katja Coneus, Maresa Sprietsma ${ }^{\dagger}$
}

July 9, 2009

\begin{abstract}
It is a well-known fact that the level of parents' education is strongly correlated with the educational achievement of their children. In this paper, we shed light on the potential channels through which human capital is transmitted from mothers to their children in early childhood. The main channels through which maternal human capital benefit the child's verbal and social skills are birth weight and father's support. Moreover, reading stories to the child is most relevant for the transmision of verbal skills whereas for social skills, a crucial channel for maternal human capital is the attendance of institutional childcare.
\end{abstract}

JEL code : I20

Keywords: early childhood, skills, intergenerational transmission

Acknowledgements: We would like to thank Christian Göbel, Andrea Mühlenweg and Pia Pinger for helpful comments and suggestions.

${ }^{*}$ Centre for European Economic Research (ZEW), L7,1, 68161 Mannheim, Germany, Email: coneus@zew.de.

${ }^{\dagger}$ Centre for European Economic Research (ZEW), L7,1, 68161 Mannheim, Germany, EMail: sprietsma@zew.de. 


\section{Introduction}

It is a well-known fact that the level of parents' education is strongly correlated with the educational achievement of their children (Coleman et al. 1966, Belzil and Hansen 2003). This effect is more robust than that of any school or institutional factors. Moreover, differences in skills between children with less versus better educated parents are observed at an early age and have lasting effects on educational attainment (Heckman 2000, Cunha et al. 2006).

In contrast to the large and significant correlation found between the educational achievement of parents and their children, the literature finds relatively small causal effects of parental years of schooling on their children's education (see e.g. Black et al. 2005). One explanation for this modest result could be the choice of the instruments. For instance, studies using changes in the years of compulsory schooling as an instrument measure the impact of an increase of only 2 or 3 years in parents' education. Instruments like costs or availability of college education apply only for a selective group of parents. By focussing on specific groups of parents or small increases in years of schooling, these studies are unable to measure the effects of important aspects of human capital such as differences in attitude towards learning and school.

Moreover, there is hardly evidence as to what is behind the observed strong intergenerational transmission of human capital. The purpose of this paper is to shed some light inside the black box of transmission of human capital by disentangling the potential channels through which human capital is transmitted from parents to their children.

Channels through which maternal human capital affects children's skills that have been studied include maternal employment, health (Currie 2009) and early institutional childcare. However, to our knowledge, only one paper looks at the impact of early parental activities with the child on children's skills: Carneiro et al.(2007) use information on outings and reading books to the child at the time the child is 1 year old. They find a positive effect of these activities on test scores at age 7-8 years. In this paper, we focus on the skills of children at age 2-3 years. The psychological and pedagogical literature shows that at this age, considerable differences in skills already emerge between children with differently educated parents (see e.g. Rowe and Goldin-Meadow 2009). Moreover, at this age, most German children have been exposed to (pre-) school and peer effects only in a limited way.

We look at relatively large differences in maternal educational attainment. We distinguish between attaining an academic education, reaching a vocational degree versus not reaching either of these levels of education. These are used as proxies for human capital, including the human capital acquired in formal education but also human capital obtained through innate ability, educational values and other favorable environmental characteristics.

Finding exogenous variation that would yield the large variation in human capital that we are interested in decomposing seems unrealistic. In effect, one hardly imagines an exogenous shock that would comply individuals to take up several years more education than they would otherwise. Moreover, we are interested in the total 'package' of human capital, including ability and motivation. Therefore, instead of aiming at a causal analysis of maternal education, 
this paper focuses on disentangling the different channels through which human capital is transmitted from mothers to their young children.

\section{Data and results}

This analysis is done using the German Socio-Economic Panel (SOEP) for the years 2003-2008. It is an annual representative national longitudinal data set which surveys households and individuals. The newly included 'mother and child' questionnaire contains detailed information on young children and their mothers starting from the time of birth. It includes a rich set of children's skills (as assessed by the mother) and the frequency of several maternal activities with the child. Removing missing observations, our sample contains 741 children of 2 to 3 years old.

We observe three types of children's skills at age three: verbal skills, motor skills and social skills. They are measured on a Vineland scale adapted to the German setting. For each type of skill, mothers were asked to assess their child's ability to perform each of five specific tasks as either yes, to some extent, or no. A 'yes' scored two points, 'to some extent' scored one point, and 'no' scored 0 points. Scores were then summed across the five tasks to create an index ranging from 0 to 10 and indicating the child's development in each of the three dimensions of skills. The assessment of the skills by the mother is subjective. However, the questions refer to very specific behaviour of the child that the mother should have little difficulty to assess irrespective of her level of education. An additional argument for using the mother's assessment is that young children tend not to behave 'as usual' in a test situation with an unknown interviewer present. We distinguish three levels of maternal education: tertiary education, vocational education and the reference level of lower education (without a secondary school degree or without a vocational degree).

We start by estimating the following baseline specification by ordinary least squares:

(1) Skill $_{\text {child }}=$ constant $+\beta_{1}$ mothervoced $+\beta_{2}$ motheruniv $+\beta_{3}$ age $+\beta_{4}$ boy $+\beta_{5}$ firstborn $+\epsilon_{\text {child }}$

By ignoring potential channels that allow maternal education to affect her child's skills, this specification yields the 'gross' estimate of the extent to which education is passed from mother to child. The coefficients on the mother education dummies therefore include all possible channels of transmission of human capital: genetic, health, environmental factors as well as activities. We control for age in months, since the children in our sample are aged between 26 and 43 months and age can be expected to have a major impact on skills. Moreover, we include a dummy for gender and for being the firstborn child. There may indeed exist innate differences in the different levels of skills at the same age between boys and girls. It is unclear whether being the firstborn child on average correlates with higher or lower skills. Firstborn children may benefit from more parental investment ceteris paribus but their parents have less experience.

We find that the level of the maternal education is significantly positively correlated with both verbal and social skills at age three, and all the more as we 
move to higher education levels (see first columns of tables 2 and 3). The correlation is stronger for verbal skills. No correlation is observed between maternal education and children's motor skills. As we are interested in decomposing the correlation between maternal human capital and children's skills, we present the remaining analysis only for social and verbal skills. ${ }^{1}$ On average, girls perform significantly better than boys regarding both verbal and social skills. Age is correlated with both higher verbal and social skills. Being the firstborn child is not significantly related to skills.

We then successively add channel variables, through which we expect maternal human capital may affect their children's level of verbal and social skills. These are variables that are dependent on the maternal human capital and potentially have an effect on the observed level of the children's skills. The considered channels are presented in Table 1 . We interpret the observed change in the value of the coefficient of maternal education following the successive inclusion of the channels as the relevance of the included channel. This interpretation is valid as long as the included variables do not themselves affect maternal human capital. This condition holds because switching to the next category of education implies investing in several additional years of schooling. This cannot occur because maternal education and the channels are measured simultaneously.

We start our investigation by including the birth weight. As can be observed in Table 1, children from the reference group of less educated mothers weigh on average less at birth than children whose mother has a higher level of education. Longitudinal studies have found that children born with low birth weight score lower on a variety of tests of intellectual and social development, (e.g. BrooksGunn et al. 1996, Black et al. 2007). In our data as well, a higher birth weight is related to both better verbal and social skills at age three. After the inclusion of birth weight, the coefficients of maternal vocational education are reduced by 14 and $17 \%$ for verbal and social skills respectively. The coefficient of academic education is reduced by $8 \%$ and $11 \%$.

The next channel we look at is the paternal support in taking care of the child. The degree of support by the father in taking care of the child is assessed subjectively by the mother on a scale of 0 (absent) to 4 (very strongly). Better educated mothers tend to declare stronger paternal support. Father support is related to significantly higher verbal and social skills at age three. The coefficient of maternal vocational education reduces by around $13 \%$ for both types of skill after inclusion of father support.

The attendance of institutional childcare is strongly correlated with maternal education as well. Whereas children with less educated mothers attend institutional childcare on average 5.2 hours a week, those with higher educated mothers spend on average 13.9 hours a week in institutional childcare. This may affect skills acquisition through the pedagogical childcare activities and through interaction with other children. We find that additional time spent in institutional child care per week is related to better social skills and is not correlated with verbal skills. Its inclusion decreases the coefficient of maternal education

\footnotetext{
${ }^{1}$ Results on motor skills are available upon request from the authors.
} 
Table 1: Descriptive Statistics (means)

\begin{tabular}{llll}
\hline \hline & no degree & $\begin{array}{l}\text { vocational } \\
\text { degree }\end{array}$ & $\begin{array}{l}\text { university } \\
\text { degree }\end{array}$ \\
\hline Visiting friends and family & $1.37^{*}$ & 1.20 & 1.14 \\
Drawing & 1.93 & 1.85 & 1.92 \\
Going to the playground & $1.76^{*}$ & 1.44 & 1.40 \\
Birth weight & $3182.33^{*}$ & 3367.33 & 3350 \\
Father's support & $2.68^{*}$ & 3.06 & 3.04 \\
Institutional child care (hours/week) & $5.13^{*}$ & 9.05 & 13.97 \\
Picture book & $2.47^{*}$ & 2.57 & 2.83 \\
Singing & $1.70^{*}$ & 2.10 & 2.46 \\
Reading stories & $1.98^{*}$ & 2.39 & 2.78 \\
\hline \hline Observations & 93 & 471 & 177 \\
\hline
\end{tabular}

Note: *indicates significant differences between the lowest education category against the mid and highest education category at the $5 \%$ level.

Source: SOEP 2003-2008.

by 11 and $20 \%$ for vocational and university education respectively. Because of selective participation, institutional child care attendance therefore seems to reinforce the social skills gap between children with less and better educated mothers.

Finally, we turn to the frequency of various activities with the child. These are measured on a scale from 0 (never) to 3 (daily). The frequency of visits to friends and family and going to the playground is significantly higher for less educated mothers whereas the frequency of drawing is not correlated with the level of maternal education (Table 1). The inclusion of these variables therefore slightly increases the skills gap between children with less versus better educated mothers. This can be observed in columns $2-4$ of Tables 2 and 3 . To the contrary, the frequency of looking at picture books, singing and reading stories to the child is significantly correlated with the level of maternal education. 


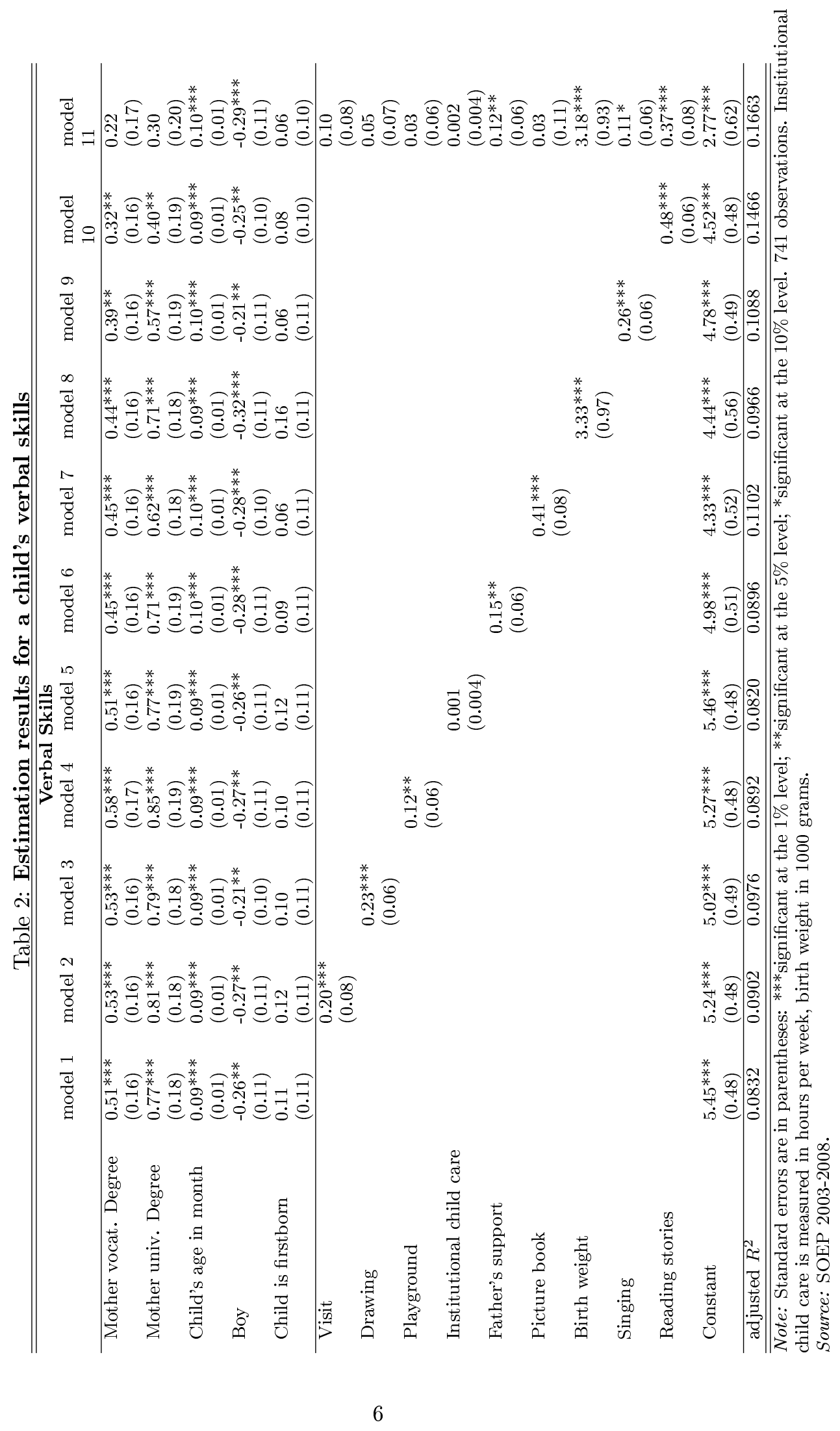




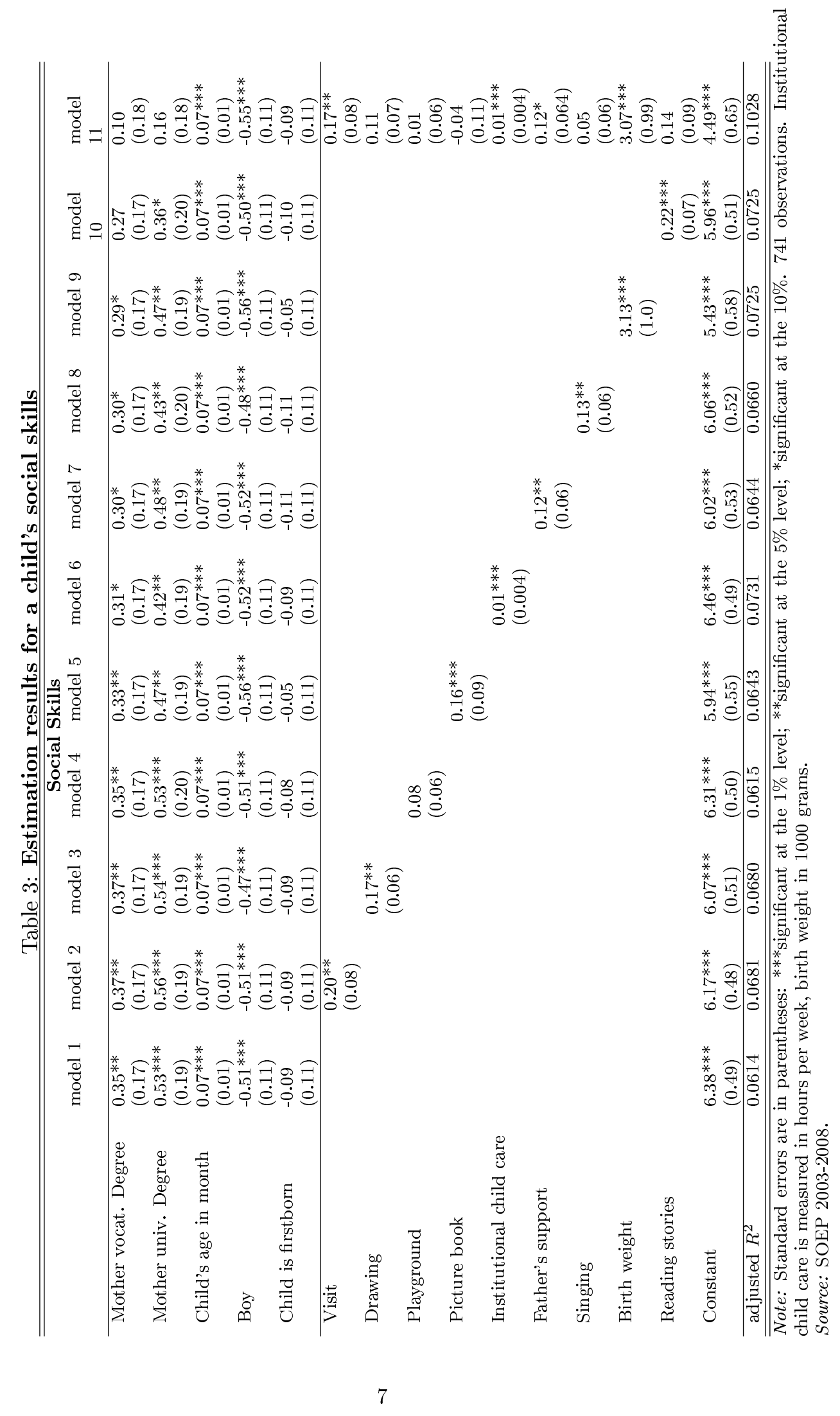


Including these activities in the estimation, we observe that the frequency of reading stories to the child has a highly significant and the largest impact on verbal and social skills at age three. The inclusion of this variable reduces the coefficient of the maternal education dummies by nearly half for verbal skills and by around $25 \%$ for social skills (see Tables 2 and 3, column 10). Singing and looking at picture books have a similar though weaker impact on the reduction of the coefficients of maternal education.

The last columns of Tables 2 and 3 present the estimates when including all channels simultaneously. In this specification, the coefficients of maternal education are no longer significantly different from zero. The channels that appear to be most relevant from this specification are father support and birth weight for both verbal and social skills. In addition, for verbal skills, reading stories and singing seem to play the most important role, whereas attending institutional childcare dominates as a channel for the correlation of maternal human capital with the child's social skills.

Our results show that parental preferences and the choice of activities affect children's verbal and social skills already at age three. Interestingly, the high relevance of reading stories as compared to other activities is also in line with the evidence from brain research. It has indeed been shown that the human brain learns speech and facts best through meaningful relations between words and ideas, which is exactly what stories are (Spitzer 2007).

\section{Conclusions}

In this paper, we studied possible channels for the intergenerational transmission of human capital in early childhood. We focus on verbal and social skills, as motor skills are not related to the level of maternal education. According to our results, the included channels together account for the entire verbal and social skill gap between children from less versus better educated mothers at age three. Birth weight and the intensity of father's support are important channels of transmission of human capital for both verbal and social skills. Moreover, reading stories to the child is most relevant for the transmission of verbal skills whereas for social skills, a crucial channel for maternal human capital is the attendance of institutional childcare. This implies that there is important scope for reducing educational inequalities by encouraging attendance of institutional childcare before age three and by increasing parental awareness of the high relevance of early verbal stimulation such as through reading stories. 


\section{References}

Belzil C. and J. Hansen (2003), 'Structural Estimates of the Intergenerational Education Correlation', Journal of Applied Econometrics 18, 679-696.

Black S.E., P.J. Devereux and K.G. Salvanes (2005), 'Why the Apple Doesn't Fall Far: Understanding Intergenerational Transmission of Human Capital', American Economic Review 95(1), 437-449.

Black S.E., P.J. Devereux and K.G. Salvanes (2007), 'From the Craddle to the Labor Market? The Effect of Birth Weight on Adult Outcomes', Quarterly Journal of Economics 122(1), 409-439.

Brooks-Gunn J., P.K. Klebanov and G.J. Duncan (1996), 'Ethnic Differences in Children's Intelligence Test Scores: Role of Economic Deprevation, Home Environment, and Maternal Characteristics', Child Development 67(2), 396408.

Carneiro P., C. Meghir and M. Parey (2007), 'Maternal Education, Home Environments and the Development of Children and Adolescents', IZA Discussion Paper 3072.

Coleman J.S. (1966), 'Equality of Educational Opportunity', Washington, DC: U.S. Department of Health, Education, and Welfare, Office of Education/National Center for Education Statistics.

Cunha F., J.J. Heckman, L.Lochner and D.V. Masterov (2006), 'Interpreting the Evidence on Life Cycle Skill Formation', in: F. Welsch and E. Hanushek, eds., The Handbook of the Economics of Education, (North Holland, Amsterdam).

Currie J. and E. Moretti (2003), 'Mothers' Education and the Intergenerational Transmission of Human Capital: Evidence from College Openings', Quarterly Journal of Economics 118(4), 1495-1532.

Currie J. (2009), 'Healthy, Wealthy, and Wise: Socioecoomic Status, Poor Health in Childhood, and Human Capital Development', Journal of Economic Literature 47 (1), 87-122.

Heckman J.J. (2000), 'Policies to Foster Human Capital', Research in Economics 54 (1), 3-56.

Rowe M. and S. Goldin-Meadow (2009), 'Differences in Early Gesture Explain SES Disparities in Child Vocabulary Size at School Entry', Science Vol. 323 Nr. 5916, 951-953

Spitzer M. (2007), Learning: The Human Brain and the School for Life, Elsevier Science Ltd (Oxfordshire, United Kingdom). 